Oriental Journal of Medicine and Pharmacology

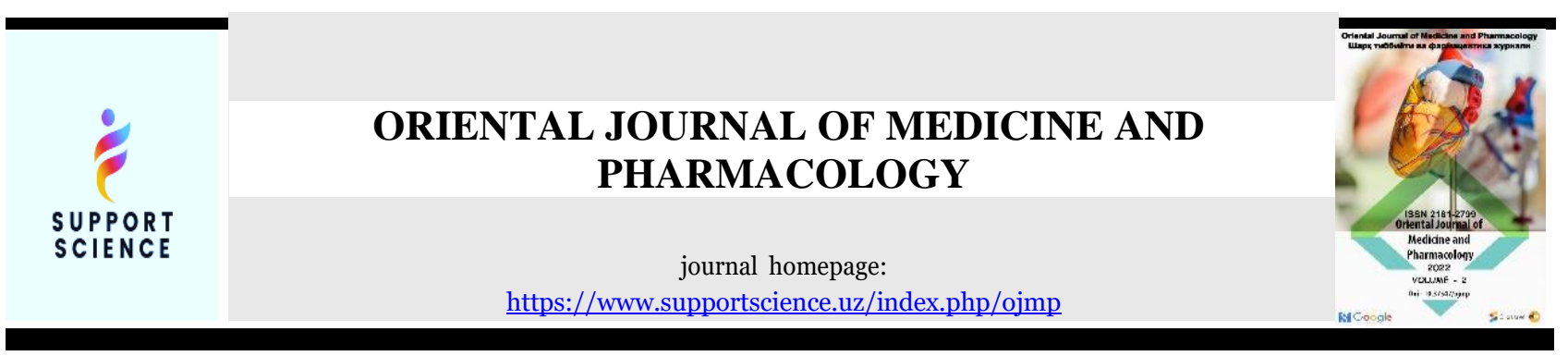

\title{
RESULTS OF AUDIOLOGICAL EXAMINATION IN ACUTE SENSORINEURAL HEARING LOSS OF VARIOUS GENESIS
}

U.S. Khasanov, U.P. Abdullaev, J.A. Djuraev

Tashkent Medical Academy, Uzbekistan

\section{ABOUT ARTICLE}

Key words: acute sensorineural hearing loss, noise, hearing, deafness.

Received: 04.01.22

Accepted: 10.01.22

Published: 15.01 .22
Abstract: This article provides an audiological description of acute sensorineural hearing loss of various genesis. One of the main problems of modern clinical audiology is hearing loss, which is a process of conversion of mechanical vibrations into energy of nerve impulses for one reason or another and subsequent damage to the auditory apparatus when the transmission from auditory receptors to the appropriate centers of the cerebral cortex is disrupted. Numerous publications in the world and local literature indicate that sensorineural hearing loss is common and very common among ENT organ diseases. According to the World Health Organization, by 2016, the number of people with socially significant hearing impairments will range from $0.6 \%$ to $20 \%$, particularly in Russia, where the number of such patients is approaching 13 million, of whom 750,000 are children, and in Europe, sensorineural hearing loss. accounts for $37.2 \%$ of auditory pathology. 


\section{ТУРЛИ ГЕНЕЗЛИ ЎТКИР СЕНСОНЕВРАЛ ЭШИТИШ ПАСТЛИГИДА АУДИОЛОГИК ТЕКШИРУВ НАТИЖАЛАРИ}

\section{У.С. Хасанов, У.П. Абдуллаев, Ж.А. Дюсураев}

Тошкент тиббиёт академияси

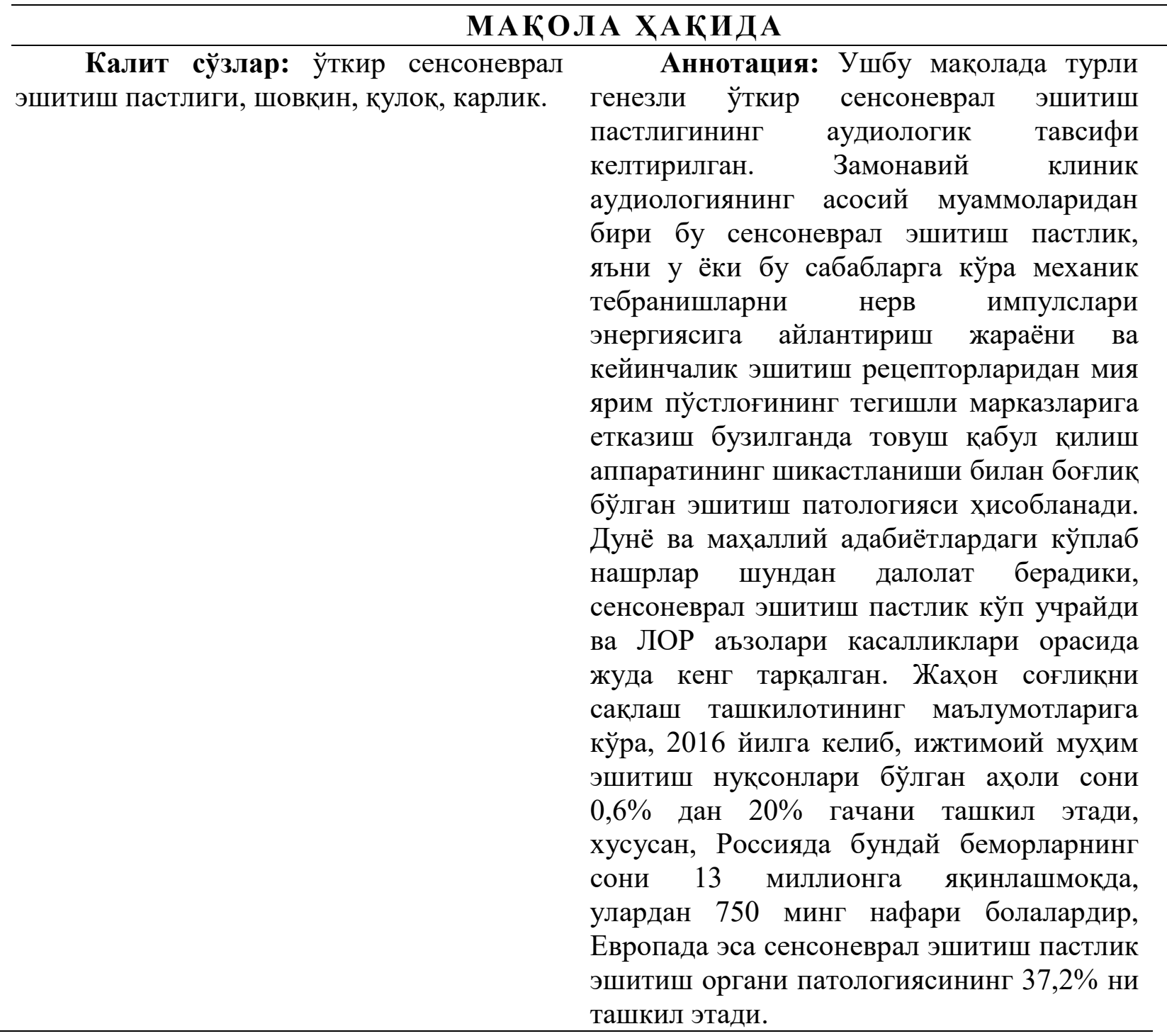




\title{
РЕЗУЛЬТАТЫ АУДИОЛОГИЧЕСКОГО ИССЛЕДОВАНИЯ ПРИ ОСТРОЙ НЕЙРОСЕНСОРНОЙ ТУГОУХОСТИ РАЗЛИЧНОГО ГЕНЕЗА
}

\author{
У.С. Хасанов, У.П. Абдуллаев, Ж.А. Джураев
}

Ташкентская медииинская академия

\begin{tabular}{lrr}
\hline \multicolumn{1}{c}{ Ключевые } & \multicolumn{1}{c}{ слова: } \\
$\begin{array}{l}\text { нейросенсорная } \\
\text { глухота. }\end{array}$ & тугоухость, шум, слух, \\
&
\end{tabular}

\section{СТ АТЬ} глухота.

Аннотация: В данной статье дано
аудиологическое нейросенсорной тугоухости различного генеза. Одной из основных проблем современной клинической аудиологии является тугоухость, представляющая собой процесс преобразования механических колебаний в энергию нервных импульсов по тем или иным причинам и последующее повреждение слухового аппарата при передаче от слуховых рецепторов к соответствующим центрам слуха. кора головного мозга нарушена. Многочисленные публикации в мировой и отечественной литературе свидетельствуют о том, что сенсоневральная тугоухость является распространенной и весьма распространенной среди заболеваний ЛОР-органов. По данным Всемирной организации здравоохранения, к 2016 г. количество людей с социально значимыми нарушениями слуха будет колебаться от $0,6 \%$ до $20 \%$, особенно в России, где число таких больных приближается к 13 млн, из них 750000 детей, а в Европе нейросенсорная тугоухость составляет $37,2 \%$ слуховой патологии.

\section{I. КИРИШ}

Ўткир эшитиш йўқолиши - одатда беморни жуда кўрқитувчи, дархол мутахассисга мурожаат қилишига сабаб бўлувчи симптомдир. Кўпинча, бу турдаги эшитиш пастлиги товушни англашнинг бузилиши хисобланади ва битта қулоқда эшитишнинг тез ва кескин пасайиши билан тавсифланади хамда баъзи холларда бош айланиши ва касалланган қулоқда шовқин бўлиши каби симптомлар билан бирга кечади. Ўткир сенсоневрал эшитиш пастлиги (ЎСНЭП) биринчи бўлиб De Kleyn [1] томонидан ёритилган. Ўшандан бери ушбу патология бўйича жуда кўп тадқиқотлар олиб борилди, аммо ушбу касалликдек, яъни этиологияси, патогенези хамда давоси бўйича жуда кўп қарамақаршиликлар бўлган бошқа бирор ларингооторинологик (ЛОР) касаллик мавжуд эмас. Тўсатдан сенсоневврал эшитиш пастлиги кўпинча 24-72 соат ичида юзага келган, тонал 
бўсағали аудиограммада, камида 3 та ёндош частотада эшитишнинг 30 дБ га ёки ундан кўпроққа ёмонлашиши кузатиладиган эшитишнинг бир томонлама йўқолиши деб таърифланади. Овозни идрок қилиш (сезиш, қабул қилиш) қобилиятининг бузилиши ёки сенсоневрал (нейросенсор, перцептив) эшитиш пастлиги кўпинча эркаклар ва аёлларда деярли бир хилда учрайди; хар 100000 ахолига 5 тадан 20 тагача одам бу патологиядан азият чекади. Жахон соғлиқни сақлаш ташкилотининг статистик маълумотларига кўра, хар йили сенсоневрал эшитиш пастликнинг 4000 тагача янги холатлари рўйхатга олинади [2-7].

Тўсатдан юзага келадиган сенсоневрал эшитиш пастлик узоқ вақтдан бери оториноларингологлар эътиборини жалб қилиб келмоқда. Ушбу клиник белги уни “тўсатдан юза келадиган карлик” ёки “эшитиш қобилиятини йўқотиш” атамаси билан номлашга сабаб бўлди (Sudden deafness - инглиз тилида, Hörstürz - немис тилида). Бундай эшитиш пастлигини мустақил нозологик шакл сифатида тан олиш ғояси аста-секин, узоқ вақт давомида шаклланди. Инглиз ва немис тилидаги илмий адабиётларда илмий қизиқишлар оммабоп бўлишининг замонавий шароитида немис муаллифларининг муаммони ечиш ва 2014 йилда чет элдаги илмий тадқиқотчиларнинг эшитиш пастлиги тасвирланган холатни мустақил шакл деб таърифлашлари билан хисоблашишлари қизиқ ва хатто бироз ғалати $[8,9]$.

Афсуски, бажарилган ишлар сони билан таққосланганда уларнинг сони кўп эмас ва улар асосан “сенсоневрал эшитиш пастлиги” атамаси билан таърифланган касалликларнинг умумий гурухида тўсатдан юзага келадиган эшитиш пасайишининг ўрнини белгилаш ва касаллик клиник белгиларини келишиб олишга бағишланган. Ушбу маънода, тўсатдан эшитиш пасайишини мустақил нозологик шакл сифатида бир овоздан тан олиниши жуда мухим ва тўсатдан эшитиш пасайишини “идиопатик эшитишнинг пасайиши” [10-14] атамаси билан хам тушуниш лозим.

Адабиётларда сенсоневрал эшитиш пасайишининг бир неча таснифи келтирилган. Касалликнинг давомийлигига қараб таснифлаш алохида қизиқиш уйғотади. Тўсатдан (бошлангандан бошлаб 12 соатдан кўп вақт ўтмаган), ўткир (1 ойгача), ўткир ости (давомийлиги 1 ойдан 3 ойгача) ва сурункали (3 ойдан ортиқ) эшитиш пасайиши фарқланади [12]. Баъзи муаллифлар алохида шакл сифатида “тўсатдан юзага келадиган карлик” ёки “эшитишнинг чақмоқсимон пасайиши”ни ажратишади $[3,9]$.

Энг қийин ва мухим муаммо ўткир (ЎСНЭП) ва тўсатдан юзага келадиган (ТСНЭП) сенсоневрал эшитиш пасайиши хисобланади, турли манбаларга кўра бундай холатларнинг частотаси барча эшитиш бузилишларининг 1 фоизидан камроғини ташкил этади $[7,8]$. 
Ўткир сенсоневрал эшитиш пастлиги бир неча кун ичида ривожланади ва тўқималарнинг хар хил даражадаги товуш ўтказувчанлиги бўйича тонал бўсағаларнинг ошиши, яъни битта ёки иккала қулоқда эшитишнинг пасайиши, нутқни тушунмаслик, товушни англай олмаслик ва қулоқдаги шовқин билан тавсифланади. Баъзи беморларда тизимли бош айланиши ва бошқа вестибуляр касалликлар кузатилади, ототопик бузилишлар, шовқинга чидамлиликнинг ёмонлашиши, баланд кескин товушлар ва бошқа симптомлар пайдо бўлиши мумкин [15].

Эшитишнинг тўсатдан сенсоневрал пасайишига патологик жараённинг чақмоқсимон ёки бир неча соат ичида ривожланиши ва эшитиш пастликнинг тўлиқ карликкача бўлган юқори даражаси хосдир. Турли тадқиқотларга кўра, ўз-ўзидан соғайиш фақат 32-65\% холлардагина учрайди [16]. Бироқ, бу масала оддий хам эмас ва янги хам эмас. Аммо, олдин эшитиш патологиясини тизимлаштириш унчалик мухим хисобланмаган бўлса, энди уни биринчи даражали деб хисоблаш лозим [17]. Ва бу тушунарли, чунки сенсоневрал эшитиш бузилиши хақидаги таълимотни шакллантиришнинг дастлабки босқичларида уни кондуктив бузилишлардан ва намоён бўлиш хусусиятлари ва юзага келиш механизмларидан фарқлаш зарурияти олдинга чиқди. Бундан ташқари, эшитишнинг овоз ўтказиш бузилишларини жаррохлик йўли билан даволаш муваффақияти сенсоневрал патологияни бироз тўсиб кўйди ва аудиологик диагностиканинг кондуктив (радикал даволашга мос) ва сенсоневрал (хар қандай даволашга бўйсунмайдиган) эшитиш пасайиши фарқланишининг асосий йўналишини белгилади [11].

Гарчи муаллифларнинг ўзлари ушбу касалликнинг патогенезига спирал ганглий хужайралари алоқадор эмас деган хулосага келишса-да, бундай кузатувлар таърифланган эшитиш пастлиги шаклининг клиник хусусиятларига мос келади, унинг келиб чиқишининг вирусли назариясини шубха остига қўйиб, лабиринтит ва тўсатдан юзага келадиган сенсоневрал эшитиш пасайиши тушунчаларини ажратиш мумкин эмас деб хисоблашади. Эхтимол, худди шу муаллифларнинг аллергик табиатли ўткир сенсоневрал эшитиш пастлиги сабаблари хақидаги замонавий ғоялар мулохазалар ва тахминлардан ташқарига чиқмайди деган хулосага келиши янада тўғри ва эхтиёткор йўлдир. Юқорида айтилганларнинг барчаси ушбу тадқиқотнинг мақсадини олдиндан белгилади.

\section{II. УШБУ ИШНИНГ МАҚСАДИ.}

Турли генезли ўткир сенсоневрал эшитиш пастлигининг аудиологик хусусиятларини ўрганишдир.

Тадқиқот мақсадига мувофиқ ва белгиланган вазифаларни бажариш учун 2018-2021 йилларда ТТА кўп тармоқли клиникасининг ЛОР бўлимига ётқизилган, эшитиши турли 
генезли ўткир сенсоневрал пасайган 82 нафар беморда клиник тадқиқотлар ўтказилди. Барча беморлар шикоятларни йиғиш, ЛОР аъзолар кўриги, қулоқ эндоскопияси ва аудиологик текширувлар йиғиндисидан иборат комплекс текширувдан ўтишди.

\section{III. НАТИЖАЛАР.}

Қулоқлардаги субъектив шовқин - бу эшитиш органи шикастланишида: хам кондуктив, хам перцептив эшитиш пасайишида юзага келадиган кенг тарқалган симптомдир. Шу муносабат билан, субъектив шовқиннинг табиати асосида муайян диагностик хулосалар чиқариш мумкин, бунда Н.В. Тимофеев, Б.В. Толоконников, К.Р. Покривапова, А.Н. Лопотко, И.В. Солдатов томонидан ишлаб чиқилган спектрал шумометрия мухим диагностик ахамиятга эга.

Биз субъектив қулоқ шовқинларининг аудиометрик текширувларини қўлладик ва турли этиологияли ЎСНЭП ва ТСНЭП бўлган 82 та беморда унинг частотаси ва интенсивлигини аниқладик. 82 та бемордан 67 нафарида $(81,7 \%)$ субъектив шовқин аниқланди. ЎСНЭП ва ТСНЭП бўлган беморларда субъектив қулоқ шовқинини ўрганиш натижалари 1-жадвалда келтирилган.

1-жадвал

\section{ЎСНЭП ва ТСНЭП бўлган беморларда субъектив кулоқ шовқинини ўрганиш} натижалари

\begin{tabular}{|c|c|c|c|c|c|c|c|c|c|c|c|c|c|}
\hline \multirow[t]{2}{*}{\begin{tabular}{|l|} 
№ \\
$\mathrm{T} / \mathrm{p}$
\end{tabular}} & \multirow[t]{2}{*}{$\begin{array}{c}\text { ЎСНЭП ва } \\
\text { ТСНЭП } \\
\text { шакллари }\end{array}$} & \multicolumn{8}{|c|}{ Субъектив шовқин частотаси (Гц) } & \multicolumn{2}{|c|}{$\begin{array}{c}\text { Субъектив } \\
\text { шовқин } \\
\text { интенсивлиги } \\
\text { (дБ) }\end{array}$} & \multirow[t]{2}{*}{\begin{tabular}{|c|} 
Субъектив \\
шовқин \\
мавжуд \\
беморлар
\end{tabular}} & \multirow[t]{2}{*}{ Жами } \\
\hline & & 125 & 250 & 500 & 1000 & 2000 & 4000 & 8000 & $\begin{array}{c}\text { Шовқ } \\
\text { ин }\end{array}$ & $10-20$ & $\begin{array}{c}21-50 \text { ва } \\
\text { юқори }\end{array}$ & & \\
\hline 1. & Юқумли & 1 & 1 & & 2 & 1 & 3 & 13 & 3 & 1 & 23 & 24 & 29 \\
\hline & a) ЎСНЭП & 1 & 1 & - & 1 & 1 & 1 & 6 & 2 & - & 13 & 13 & 17 \\
\hline & б) ТСНЭП & - & & & 1 & - & 2 & 7 & 1 & 1 & 10 & 11 & 12 \\
\hline 2. & Қон томир & 1 & - & 1 & 1 & 1 & 1 & 5 & 3 & 2 & 11 & 13 & 18 \\
\hline & a) ЎСНЭП & - & & & - & 1 & & 1 & 1 & 0 & 3 & 3 & 4 \\
\hline & б) ТСНЭП & 1 & & 1 & 1 & - & 1 & 4 & 2 & 2 & 8 & 10 & 14 \\
\hline 3. & $\begin{array}{c}\text { Аллергик } \\
\text { ЎСНЭП }\end{array}$ & 2 & 1 & & & 1 & 2 & 3 & 8 & 3 & 14 & 17 & 17 \\
\hline 4. & $\begin{array}{c}\text { Ототоксик } \\
\text { ЎСНЭП }\end{array}$ & & - & - & 1 & - & 1 & - & 1 & 1 & 2 & 3 & 8 \\
\hline 5. & $\begin{array}{c}\text { Травматик } \\
\text { ЎСНЭП }\end{array}$ & - & - & - & 1 & - & 1 & 3 & 2 & - & 7 & 7 & 7 \\
\hline
\end{tabular}




\begin{tabular}{|c|c|c|c|c|c|c|c|c|c|c|c|c|}
\hline 6. $\begin{array}{c}\text { Бўйин умуртқаси } \\
\text { остеохондрози } \\
\text { фонида (ТСНЭП) }\end{array}$ & & & - & - & - & 2 & 1 & & 3 & 3 & 3 \\
\hline ЖАМИ: & 4 & 2 & 1 & 5 & 3 & 8 & 26 & 18 & 7 & 60 & 67 & 82 \\
\hline & $5,9 \%$ & $2,9 \%$ & $1,4 \%$ & $7,4 \%$ & $4,4 \%$ & $11,9 \%$ & $38,8 \%$ & $26,8 \%$ & $10,5 \%$ & $89,5 \%$ & $81,7 \%$ & $100 \%$ \\
\hline
\end{tabular}

Жадвалдан кўриниб турибдики, 82 нафар бемордан 67 нафарида $(81,7 \%)$ субъектив кулоқ шовқини бўлган, улардан 43 таси $(64,1 \%)$ ЎСНЭП ва 24 таси $(35,9 \%)$ ТСНЭП билан касалланган. Субъектив шовқиннинг частоталарини ўрганаётганда биз қуйидагиларни аниқладик: 67 нафар бемордан 42 тасида (62,6\%), яъни ЎСНЭП бўлган 24 нафар беморда (57,1\%), ТСНЭП бўлган 18 нафар (42,9\%) беморда ўрта частотали ва юқори частотали шовқин аниқланди, бу перцептив эшитиш пастлигига хосдир. ЎСНЭП билан оғриган беморларда қулоқ шовқини устунлик қилди. Этиологик омилга кўра қуйидаги хусусиятлар аникланди. Аллергик этиологияда 17 нафар беморнинг 3 тасида (17,6\%) паст частотали субъектив шовқин қайд этилди, унинг интенсивлиги 10 дБ дан 50 дБ гача бўлди, бу сенсоневрал эшитиш пастлигининг бошқа шаклларига хос эмас.

Шундай қилиб, турли хил этиологияли ЎСНЭП ва ТСНЭП билан касалланган беморларда кулоқнинг субъектив шовқинини ўрганиш натижалари шуни кўрсатдики, 42 нафар (62,6\%) беморнинг аксариятида субъектив шовқин юқори частотали характерга эга бўлди, бу эса кохлеар рецептор зарарланганлигини кўрсатади.

Биз томонимиздан кузатилган, ўткир ва тўсатдан эшитиш қобилиятини йўқотган ва кар бўлган беморларнинг аксариятида эшитиш пастлиги яққол намоён бўлди.

Текширилган 82 нафар беморнинг 54 тасида (65,8\%) ЎСНЭП ва 28 нафарида (34,2\%) ТСНЭП аниқланган, улардан 30 нафари пичирлаган товушни сезмайди (ЎСНЭП - 16 та (53,3\%), ТСНЭП - 14 та (46, 7\%)), 0,5 м дан 2 м масофагача - 12 нафар (7 та ЎСНЭП ва 5 та ТСНЭП билан), 3 м дан 6 м масофагача - 40 нафар (ЎСНЭП 30 та ва ТСНЭП 10 та).

Оғзаки (сўзлашиш) нутқни 8 та бемор эшитмайди, улардан 3 нафарида тўсатдан сенсоневрал эшитиш пастлиги мавжуд, нутқни эшитиши 0,5-2 м оралиғида - 17 та бемор ва 3-6 м масофада - 57 та бемор, улардан 20 нафар бемор - ТСНЭП. Буларнинг барчасини 2-жадвалда келтирилган маълумотлардан кўриш мумкин.

Турли этиологияли ЎСНЭП ва ТСНЭП бўлган беморларда пичирлаш ва сўзлашиш нутқларини эшитиш 


\begin{tabular}{|c|c|c|c|c|c|c|c|c|c|c|}
\hline \multirow[t]{2}{*}{ № } & \multirow{2}{*}{$\begin{array}{l}\text { ЎСНЭП ва } \\
\text { ТСНЭП } \\
\text { шакллари }\end{array}$} & \multicolumn{4}{|c|}{$\begin{array}{c}\text { Пичирлаш нутқини } \\
\text { эшитиш (м) }\end{array}$} & \multicolumn{4}{|c|}{$\begin{array}{c}\text { Сўзлашиш нутқини } \\
\text { эшитиш (м) }\end{array}$} & \multirow[t]{2}{*}{$\begin{array}{c}\text { Барча } \\
\text { беморлар }\end{array}$} \\
\hline & & $\begin{array}{l}\text { Эшит- } \\
\text { мади }\end{array}$ & 0,5 & $1-2$ & $3-6$ & $\begin{array}{l}\text { Эшит- } \\
\text { мади }\end{array}$ & 0,5 & $1-2$ & $3-6$ & \\
\hline \multirow{3}{*}{1.} & Юқумли & 8 & 1 & 3 & 17 & 1 & 1 & 3 & 24 & $29(34,8 \%)$ \\
\hline & a) ЎСНЭП & 2 & 1 & 1 & 13 & - & 1 & 1 & 15 & $17(60,4 \%)$ \\
\hline & б) ТСНЭП & 6 & - & 2 & 4 & 1 & - & 2 & 9 & $12(39,6 \%)$ \\
\hline \multirow{3}{*}{2.} & Қон томир & 10 & 1 & 1 & 6 & 3 & 2 & 4 & 9 & $18(22 \%)$ \\
\hline & a) ЎСНЭП & 3 & - & - & 1 & 1 & 1 & 1 & 1 & $4(24 \%)$ \\
\hline & б) ТСНЭП & 7 & 1 & 1 & 5 & 2 & 1 & 3 & 8 & $14(76 \%)$ \\
\hline 3. & Аллергик ЎСНЭП & 6 & - & 2 & 9 & 1 & 1 & 3 & 12 & $17(20,8 \%)$ \\
\hline 4. & $\begin{array}{c}\text { Ототоксик } \\
\text { ЎСНЭП }\end{array}$ & 3 & 1 & - & 4 & 2 & - & 2 & 4 & $8(10 \%)$ \\
\hline 5. & $\begin{array}{c}\text { Травматик } \\
\text { ЎСНЭП }\end{array}$ & 2 & - & 2 & 3 & 1 & & 1 & 5 & $7(8 \%)$ \\
\hline \multirow[t]{2}{*}{6.} & $\begin{array}{c}\text { Бўйин умуртқаси } \\
\text { остеохондрози } \\
\text { фонида (ТСНЭП) }\end{array}$ & 1 & 1 & - & 1 & & - & - & 3 & $3(4 \%)$ \\
\hline & ЖАМИ: & 30 & 4 & 8 & 40 & 8 & 4 & 13 & 57 & $82(100 \%)$ \\
\hline
\end{tabular}

Бизнинг маълумотларимиз шундан далолат берадики, пичирлаш ва сўзлашиш нутқини эшитишни текшириш ЎСНЭП ва ТСНЭП турли шаклларини дастлабки ташхислашда маълум диагностик ахамиятга эга. Ушбу оддий усул билан эшитиш даражасини аниқлашда текширилган беморларда қуйидаги хусусиятларни аниқладик:

Биринчидан, аллергия туфайли эшитиш бузилганда, пичирлаш ва сўзлашиш нутқларини эшитишдаги фарқ, одатда, бошқа этиологияли ЎСНЭП фонидаги эшитиш пасайишидан сезиларли даражада паст бўлди.

Иккинчидан, аллергик этиологияли ЎСНЭП бўлган беморларда соғлом қулоқ Барани трашеткаси билан ёпилганда, ЎСНЭП нинг бошқа шаклларидан фарқли ўлароқ, нутқни англаш кам ўзгарди.

Аудиометрик эгри чизикларнинг конфигурациясини тавсифловчи маълумотлар, 500, 1000, 2000 ва 4000 Гц нутқ частоталарида хаво-суяк ўтказувчанлиги бўйича эшитиш чегарасининг ўртача қиймати, ЎСНЭП ва ТСНЭП нинг хар хил шаклларда хаво-суяк ўтказувчанлиги эгри чизиқлари орасидаги интервал кўрсаткичлар 3-жадвалда келтирилган. 
ЎСНЭП ва ТСНЭП бўлган беморларда эшитишни тонал-чегара аудиометрия усули бўйича текшириш маълумотлари

\begin{tabular}{|c|c|c|c|c|c|c|c|c|c|c|c|c|c|c|}
\hline \multirow[b]{2}{*}{$\begin{array}{l}\text { № } \\
\text { T/p }\end{array}$} & \multirow[b]{2}{*}{$\begin{array}{c}\text { ЎСНЭП ва } \\
\text { ТСНЭП } \\
\text { шакллари }\end{array}$} & \multirow[b]{2}{*}{$\begin{array}{c}\text { Жами } \\
\text { беморлар }\end{array}$} & \multicolumn{4}{|c|}{ Аудиометрик эгри чизиқ тури } & \multicolumn{8}{|c|}{$\begin{array}{c}\text { Товушни хавода ўтказишда } 4 \text { та нутқ частотасида эшитиш } \\
\text { чегараларининг ўртача қиймати, дБ. }\end{array}$} \\
\hline & & & $\begin{array}{c}\text { Кўтарил } \\
\text { увчи }\end{array}$ & $\begin{array}{c}\text { Тушувч } \\
\text { и }\end{array}$ & $\begin{array}{c}\text { Гори- } \\
\text { зонтал }\end{array}$ & \begin{tabular}{|c|} 
Гори- \\
зонтал- \\
тушувчи
\end{tabular} & 20 гача & $21-30$ & $31-40$ & $41-50$ & $51-60$ & $61-70$ & $71-80$ & $\begin{array}{c}81 \text { ва } \\
\text { юқори }\end{array}$ \\
\hline \multirow[t]{3}{*}{1.} & Юқумли & $29(34,8 \%)$ & - & 1 & 3 & 25 & - & 12 & 4 & 6 & 1 & 3 & 1 & 2 \\
\hline & a) ЎСНЭП & $17(60,4 \%)$ & - & 1 & 1 & 15 & - & 9 & 3 & 4 & - & - & - & 1 \\
\hline & б) ТСНЭП & $12(39,6 \%)$ & - & - & 2 & 10 & - & 3 & 1 & 2 & 1 & 3 & 1 & 1 \\
\hline \multirow[t]{3}{*}{2.} & Қон томир & $18(22 \%)$ & - & & 7 & 11 & - & 2 & 4 & 3 & 4 & 2 & 1 & 2 \\
\hline & a) ЎСНЭП & $4(24 \%)$ & - & - & 1 & 3 & - & 1 & 1 & 1 & 1 & - & - & - \\
\hline & б) ТСНЭП & $14(76 \%)$ & - & - & 7 & 7 & - & 1 & 3 & 2 & 3 & 2 & 1 & 2 \\
\hline 3. & $\begin{array}{l}\text { Аллергик } \\
\text { ЎСНЭП }\end{array}$ & $17(20,8 \%)$ & - & 1 & 3 & 13 & - & 3 & 2 & 5 & 4 & 2 & 1 & - \\
\hline 4. & $\begin{array}{l}\text { Ототоксик } \\
\text { ўсНЭП }\end{array}$ & $8(10 \%)$ & - & 1 & 1 & 6 & - & 1 & 4 & 2 & - & - & 1 & - \\
\hline 5. & $\begin{array}{c}\text { Травматик } \\
\text { УСНЭП }\end{array}$ & $7(8 \%)$ & - & 1 & - & 6 & - & 3 & 1 & 2 & 1 & & - & - \\
\hline \multirow[t]{2}{*}{6.} & $\begin{array}{c}\text { Бўйин умуртқаси } \\
\text { остеохондрози } \\
\text { фонида (ТСНЭП) }\end{array}$ & $3(4 \%)$ & - & 1 & & 2 & - & 1 & 1 & 1 & - & - & - & - \\
\hline & ЖАМИ: & $82(100 \%)$ & - & $5(6 \%)$ & $\begin{array}{c}14 \\
(18,4 \%)\end{array}$ & $\begin{array}{c}62 \\
(75,6 \%)\end{array}$ & - & 22 & 16 & 19 & 10 & 7 & 4 & 4 \\
\hline
\end{tabular}


Жадвалда келтирилган маълумотлардан кўриниб турибдики, 62 та беморда турли хил этиологияли ўткир ва тўсатдан сенсоневрал эшитиш пасайишида аудиометрик эгри чизиқларнинг конфигурацияси горизонтал пасайган. 62 нафар беморнинг 19 тасида ТСНЭП ва 43 тасида ЎСНЭП мавжуд. Бундай эгри чизиқли конфигурациялар, хусусан, юқумли шаклда 29 нафар бемордан 25 тасида, қон томирлар шаклида - 18 тадан 11 тасида, медикаментоз шаклда - 8 тадан 6 тасида, травматик шаклда - 7 тадан 6 тасида, умуртқанинг бўйин қисми остеохондрози туфайли эшитиш пасайганда - 3 тадан 2 тасида ва аллергик этиологияли ОСТ да - 17 та бемордан 13 тасида кузатилди.

Шундай қилиб, турли хил этиологияли ЎСНЭП ва ТСНЭП бўлган беморларда тонал бўсаға аудиометрия маълумотлари таққосланганда қуйидагилар аниқланди: аудиограмма эгри чизиқларининг конфигурацияси сенсоневрал эшитиш пасайишининг барча белгиларини, яъни хаво-суяк интервалисиз пасайиш, горизонтал ва горизонтал-пасайишни эслатади. Аллергик, травматик (минали портловчи) ва юқумли этиологияли ЎСНЭП бўлган беморларга келсак, уларнинг характерли хусусияти хаво-суяк интервалининг мавжудлиги хисобланади.

ЎСНЭП бўлган 8 та беморда ототоксик антибиотиклар фонида ўтказилган аудиометрик текширувлар шуни кўрсатдики, 6 та кишида (75\%) аудиограмма эгри чизиғи горизонтал-пасаювчи хусусиятга эга бўлди ва 1 та (12,5\%) беморда горизонтал тип ва 1 та (12,5\%) беморда суяк-хаво интервалисиз горизонтал-пасаювчи тип кузатилди.

Эшитиш холатини ўрганишнинг асосий усули сифатида тонал бўсаға аудиометрияни ўтказа туриб, шуни таъкидлаш керакки, эшитиш бўсағалари эшитиш функциясини тўлиқ тавсифлай олмайди, чунки одамлар ўртасидаги эшитиш мулоқоти юқори интенсивлик даражасида амалга оширилади.

ЎСНЭП ва ТСНЭП билан оғриган 67 нафар беморда тонал бўсаға аудиометрия билан бир қаторда Лушер бўйича овоз кучини идрок этишнинг дифференциал чегарасини аниқлаш мақсадида “юқори даражадаги аудиометрия” ва 500, 1000, 2000, 4000 Гц частоталарида “SI-SI” (ёки “ИМПИ”) тест товуш интенсивлигининг кичик ўсиш индексини аниқлаш ўтказилди. Текширилаётган беморларда товуш кучини сезиш дифференциал чегарасининг кўрсаткичи бўйича баланд овознинг тезлашиш феноменининг (БОТФ) мавжудлиги ва унинг намоён бўлиш даражаси бахоланди. Ушбу тадқиқотлар натижалари 4-жадвалда келтирилган.

Жадвалда келтирилган маълумотлардан кўриниб турибдики, БОТФ асосан юқумли, қон томир, медикаментоз ва травматик этиологияли ва бўйин умуртқаси остеохондрози туфайли эшитиш пасайиши бўлган ТСНЭП ва ЎСНЭП ли беморларга хосдир. Аллергик этиологияли ЎСНЭП бўлган беморларда, бошқа шакллардан фарқли ўлароқ, БОТФ 17 та 
бемордан 13 тасида (76,5\%) манфий ва фақат 3 тасида $(17,6 \%)$ кучсиз мусбат ва 1 та (5,9\%) беморда мусбат бўлди.

Шундай қилиб, аллергик бўлмаган этиологияли ЎСНЭП ва ТСНЭП да 67 та бемордан 51 тасида $(76,1 \%)$ ва аллергик этиологияли ЎСНЭП бўлган 16 та (23,9\%) беморда суяк ўтказувчанлиги бўйича эшитиш қобилияти пасайганлигидан қатъий назар, мусбат ва кучсиз мусбат БОТФ қайд этилди.

4-жадвал

ЎСНЭП ва ТСНЭП нинг турли шакллари бўлган беморларда овоз кучини идрок қилиш дифференциалланган чегараси кўрсаткичлари бўйича баланд овоз тезлашиш феноменининг намоён бўлиши

\begin{tabular}{|c|c|c|c|c|c|c|}
\hline \multirow[t]{2}{*}{ № } & \multirow{2}{*}{$\begin{array}{c}\text { ЎСНЭП ва ТСНЭП } \\
\text { шакллари }\end{array}$} & \multicolumn{4}{|c|}{ Феноменнинг намоён бўлиши } & \multirow{2}{*}{$\begin{array}{c}\text { Жами } \\
\text { беморлар }\end{array}$} \\
\hline & & Манфий & $\begin{array}{l}\text { Кучсиз } \\
\text { мусбат }\end{array}$ & Мусбат & $\begin{array}{l}\text { Кучли } \\
\text { мусбат }\end{array}$ & \\
\hline 1. & $\begin{array}{l}\text { Юкумли } \\
\text { a) ЎСНЭП } \\
\text { б) ТСНЭП }\end{array}$ & $\begin{array}{l}1 \\
1\end{array}$ & $\begin{array}{l}1 \\
1\end{array}$ & $\begin{array}{l}6 \\
4 \\
2\end{array}$ & $\begin{array}{c}14 \\
8 \\
6\end{array}$ & $\begin{array}{c}22 \\
14 \\
8\end{array}$ \\
\hline 2. & $\begin{array}{l}\text { Қон томир } \\
\text { a) ЎСНЭП } \\
\text { б) ТСНЭП }\end{array}$ & & $\begin{array}{l}2 \\
2\end{array}$ & $\begin{array}{l}5 \\
4 \\
1\end{array}$ & $\begin{array}{l}7 \\
3 \\
4\end{array}$ & $\begin{array}{c}14 \\
9 \\
5\end{array}$ \\
\hline 3. & Аллергик ЎСНЭП & 12 & 3 & 1 & - & 16 \\
\hline 4. & Ототоксик ЎСНЭП & & & 7 & 1 & 8 \\
\hline 5. & Травматик ЎСНЭП & - & 1 & 1 & 2 & 4 \\
\hline 6. & $\begin{array}{c}\text { Бўйин умуртқаси } \\
\text { остеохондрози фонида } \\
\text { (ТСНЭП) }\end{array}$ & - & - & 2 & 1 & 3 \\
\hline & ЖАМИ: & $\begin{array}{c}13 \\
19,4 \%\end{array}$ & $\begin{array}{c}7 \\
10,5 \%\end{array}$ & $\begin{array}{c}22 \\
32,8 \%\end{array}$ & $\begin{array}{c}25 \\
37,3 \%\end{array}$ & $\begin{array}{c}67 \\
100 \%\end{array}$ \\
\hline
\end{tabular}

ЎСНЭП ва ТСНЭП бўлган беморларнинг аудиологик хусусиятларини аниқлаштириш учун биз барча 82 та беморда эшитиш дискомфорти бўсағаси кўрсаткичи бўйича оқ шовқинга чидамлиликни ўргандик. Ўтказилган тадқиқотлар натижалари 5жадвалда келтирилган.

Жадвалдан кўриниб турибдики, ЎСНЭП ва ТСНЭП бўлган 82 нафар беморнинг 58 тасида филтрланган 1/3 октава шовқинга чидамлилик у ёки бу даражада пасайган: 37 та (63,8\%) (ТСНЭП билан - 28, ЎСНЭП билан - 9) беморда 70-80 дБ шовқин интенсивлигида ёқимсиз хислар пайдо бўлди. Шубхасиз, бу маълумот диагностикада қизиқиш уйғотади, 
чунки 1/3 октава шовқинга чидамлиликнинг ўзгариши сенсоневрал эшитиш пасайишига хосдир. Ушбу кўрсаткич одатда $1 / 3$ октава шовқинга чидамли бўлган ЎСНЭПга (шу жумладан аллергик этиологияли) хос эмас.

5-жадвал

Ўткир ва тўсатдан сенсоневрал эшитиш пасайишининг турли шакллари бўлган беморларда эшитиш дискомфорти чегаралари

\begin{tabular}{|c|c|c|c|c|c|c|c|c|}
\hline \multirow{2}{*}{$\begin{array}{l}\text { № } \\
\text { T/p }\end{array}$} & \multirow{2}{*}{$\begin{array}{c}\text { ЎСНЭП ва } \\
\text { ТСНЭП } \\
\text { шакллари }\end{array}$} & \multirow{2}{*}{$\begin{array}{l}\text { Беморларнинг } \\
\text { умумий сони }\end{array}$} & \multirow{2}{*}{$\begin{array}{c}\text { Текширилган } \\
\text { беморлар } \\
\text { сони }\end{array}$} & \multicolumn{5}{|c|}{ Эшитиш дискомфорти чегараси, дБ } \\
\hline & & & & $40-50$ & $51-60$ & $61-70$ & $71-80$ & $81-90$ \\
\hline 1. & $\begin{array}{l}\text { Юкумли } \\
\text { a) ЎСНЭП } \\
\text { б) ТСНЭП }\end{array}$ & $\begin{array}{l}29 \\
17 \\
12\end{array}$ & $\begin{array}{c}18 \\
7 \\
11\end{array}$ & - & - & - & $\begin{array}{c}13 \\
2 \\
11\end{array}$ & $\begin{array}{l}5 \\
5 \\
0\end{array}$ \\
\hline 2. & $\begin{array}{l}\text { Қон томир } \\
\text { a) ЎСНЭП } \\
\text { б) ТСНЭП }\end{array}$ & $\begin{array}{c}18 \\
4 \\
14\end{array}$ & $\begin{array}{c}18 \\
4 \\
14\end{array}$ & - & - & - & $\begin{array}{c}15 \\
1 \\
14\end{array}$ & $\begin{array}{l}3 \\
3 \\
0\end{array}$ \\
\hline 3. & $\begin{array}{c}\text { Аллергик } \\
\text { ЎсНЭП }\end{array}$ & 17 & 10 & - & - & - & 1 & 9 \\
\hline 4. & $\begin{array}{c}\text { Ототоксик } \\
\text { ЎСНЭП }\end{array}$ & 8 & 5 & - & - & - & 3 & 2 \\
\hline 5. & $\begin{array}{c}\text { Травматик } \\
\text { ЎСНЭП }\end{array}$ & 7 & 4 & - & - & - & 2 & 2 \\
\hline 6. & \begin{tabular}{|c|} 
Бўйин \\
умуртқаси \\
остеохондрози \\
фонида \\
(ТСНЭП) \\
\end{tabular} & 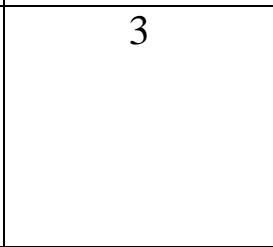 & 3 & - & - & - & 3 & 0 \\
\hline & ЖАМИ: & $82(100 \%)$ & $58(70,7 \%)$ & $(0 \%)$ & $(0 \%)$ & $(0 \%)$ & $\begin{array}{c}37 \\
(63,8 \%)\end{array}$ & $\begin{array}{c}21 \\
(36,2 \%)\end{array}$ \\
\hline
\end{tabular}

Ички кулоқдаги товушни сезиш аппаратининг функционал холатини бахолаш учун нутқ аудиометрияси катта ахамиятга эга. Тадқиқотлар шуни кўрсатдики, текширилган 82 нафар бемордан 48 нафарида $(58,4 \%)$ нутқни англаш қобилияти 100\% йўқолган, 34 та (41,6\%) беморда нутқни англаш қобилияти 100\% сақланган. Турли хил этиологияли ЎСНЭП ва ТСНЭП билан оғриган беморларда нутқни англашни тавсифловчи аниқ маълумотлар 6-жадвалда келтирилган.

Келтирилган жадвалдан кўриниб турибдики, юқумли этиологияли 29 нафар бемордан 16 нафарида (55,1\%) нутқни англаш 100\% йўқолган, қолган 13 та (44\%) беморда эса $100 \%$ сақланиб қолган, шу билан бирга ушбу гурухдаги барча беморларда нутқни 
англаш эгри чизиғи текис характерга эга бўлди. 29 нафар бемордан 16 тасида (55,1\%) 110 дБ гача бўлган нутқ интенсивлигида нутқни англаш 100\%бўлмади.

Қон томир этиологияли 18 нафар беморда ўтказилган нутқ аудиометрияси 17 та (94\%) беморда, медикаментоз этиологияда - 8 та бемордан 5 тасида (62,5\%), травматик этиологияда 7 та бемордан 5 тасида $(71,4 \%)$ ва буйин умуртқаси остеохондрози фонидаги эшитиш пасайишида - 3 та бемордан 2 тасида (66\%) нутқни англаш 100\% йўқолганлиги аниқланди.

Нутқ аудиометрияси аллергик этиологияли ЎСНЭП бўлган 17 та бемордан фақат 3 та (18\%) беморда нутқни англаш 100\% йўқолганлигини аниқлади. 14 та беморда нутқни англаш 100\% бўлди, бу 82\% ни ташкил қилади. Шуни таъкидлаш керакки, ушбу гурухдаги беморларда нутқ интенсивлигининг 110 дБгача кўтарилиши, бошқа ЎСНЭП шаклларидан фарқли ўлароқ, нутқ англашни ёмонлашишига олиб келмайди (6-жадвал).

Шундай қилиб, аллергик табиатли ўткир эшитиш пасайиши бўлган 14 та (82\%) беморларнинг аксариятида нутқни англаш ўзгармайди, яъни товуш қабул қилиш аппарати чуқур зарарланишидан далолат берувчи бундай бузилишларга учрамайди. 
6-жадвал

Турли этиологияли ўткир ва тўсатдан сенсоневрал эшитиш пасайган беморларда нутқ аудиометрияси маълумотлари

\begin{tabular}{|c|c|c|c|c|c|c|c|c|c|c|}
\hline \multirow{3}{*}{$\begin{array}{l}\text { № } \\
\mathbf{T} / \mathbf{p} \\
\end{array}$} & \multirow{3}{*}{$\begin{array}{c}\text { ЎСНЭП ва ТСНЭП } \\
\text { шакллари }\end{array}$} & \multicolumn{5}{|c|}{ Нутқни англаш \%да } & \multirow[t]{3}{*}{$100 \%$ йўк } & \multirow{2}{*}{\multicolumn{2}{|c|}{$\begin{array}{c}110 \text { дБ } \\
\text { интенсивликда } \\
\text { нутқни англаш }\end{array}$}} & \multirow{3}{*}{$\begin{array}{c}\text { Умумий } \\
\text { сони }\end{array}$} \\
\hline & & \multirow{2}{*}{$\begin{array}{c}\text { Нутқни } \\
\text { англаш } \\
\text { чегараси }\end{array}$} & \multirow[t]{2}{*}{20} & \multirow[t]{2}{*}{$\mathbf{5 0}$} & \multirow[t]{2}{*}{80} & \multirow[t]{2}{*}{100} & & & & \\
\hline & & & & & & & & 100 \% йўқ & $100 \%$ & \\
\hline \multirow[t]{3}{*}{1} & Юқумли & 29 & 29 & 29 & 29 & 13 & 16 & 16 & 13 & 29 \\
\hline & a) ЎСНЭП & 19 & 19 & 19 & 29 & 13 & 6 & 6 & 13 & 19 \\
\hline & б) ТСНЭП & 10 & 10 & 10 & 0 & 0 & 10 & 10 & 0 & 10 \\
\hline 2 & $\begin{array}{l}\text { Қон томир } \\
\text { a) ЎСНЭП } \\
\text { б) ТСНЭП }\end{array}$ & $\begin{array}{c}18 \\
4 \\
14\end{array}$ & $\begin{array}{c}18 \\
4 \\
14\end{array}$ & $\begin{array}{c}18 \\
4 \\
14\end{array}$ & $\begin{array}{c}18 \\
4 \\
14\end{array}$ & $\begin{array}{l}1 \\
1 \\
0\end{array}$ & $\begin{array}{c}17 \\
3 \\
14\end{array}$ & $\begin{array}{c}17 \\
3 \\
14\end{array}$ & $\begin{array}{l}1 \\
1 \\
0\end{array}$ & $\begin{array}{c}18 \\
4 \\
14\end{array}$ \\
\hline 3 & Аллергик ЎСНЭП & 17 & 17 & 17 & 17 & 17 & 3 & 3 & 14 & 17 \\
\hline 4 & Ототоксик ЎСНЭП & 8 & 8 & 8 & 8 & 3 & 5 & 5 & 3 & 8 \\
\hline 5 & Травматик ЎСНЭП & 7 & 7 & 7 & 7 & 2 & 5 & 5 & 2 & 7 \\
\hline \multirow[t]{2}{*}{6} & $\begin{array}{c}\text { Бўйин умуртқаси } \\
\text { остеохондрози фонида } \\
\text { (ТСНЭП) }\end{array}$ & 3 & 3 & 3 & 3 & 3 & 2 & 1 & 2 & 3 \\
\hline & ЖАМИ: & $82(100 \%)$ & $82(100 \%)$ & $\begin{array}{c}82 \\
(100 \%)\end{array}$ & $\begin{array}{c}82 \\
(100 \%)\end{array}$ & $\begin{array}{c}34 \\
(41,6 \%)\end{array}$ & $\begin{array}{c}48 \\
(58,5 \%)\end{array}$ & $48(58,5 \%)$ & $34(41,5 \%)$ & $82(100 \%)$ \\
\hline
\end{tabular}


Шундай қилиб, бизнинг кузатувларимиз шуни кўрсатдики, юқумли, қон томир, медикаментоз, травматик этиологияли ва буйин умуртқаси остеохондрози фонида юзага келадиган ЎСНЭП ва ТСНЭП билан касалланган 82 нафар бемордан 48 тасида (58,5\%) нутқ аудиометриясининг бўсаға ва бўсаға усти интенсивлигида нутқни англаш 100\% йўқолади. ЎСНЭП ва ТСНЭП бўлган беморларда катта фарқ топилмади. Шу билан бирга, аллергик табиатли ЎСНЭП бўлган беморларнинг 14 тасида (82\%), яъни аксарият қисмида, бошқа этиологияли ЎСНЭП билан таққослаганда, нутқни англаш 100\% сақланади ва ушбу беморларда эгри чизиқ конфигурацияси характери овоз ўтказувчи тизим бузилишларига мос келади. Бу шуни кўрсатадики, аллергик этиологияли ЎСНЭП да кохлеар рецепторлар функцияси кўпчилик беморларда сақланиб қолади.

Эшитадиган частоталарнинг пастки чегарасини аниқлаш перцептив ва кондуктив эшитиш пастлигининг дифференциал диагностикасида нисбатан содда ва ишончли усулдир.

Ўткир ва тўсатдан сенсоневрал эшитиш пасайишининг турли шакллари бўлган 82 та беморда эшитилган частоталарнинг пастки чегарасини Б.М. Сагалович (1965) усули билан аниқладик. Ушбу текширув натижалари 7-жадвалда келтирилган.

Жадвал шуни кўрсатадики, сезиладиган частоталарнинг пастки чегараси ўткир эшитиш йўқолган беморларга, хусусан, аллергик этиологияли ЎСНЭП касаллигига чалинган беморларга қараганда тўсатдан эшитиш пасайган беморларда анча паст.

Юқоридаги жадвалдан кўриниб турибдики, юқумли этиологияли ЎСНЭП бўлган 17 та бемордан 13 тасида (82,4\%) эшитиладиган частоталарнинг пастки чегараси 16-20 Гц; 4 та (23,5\%) беморда - 20-30 Гц, ТСНЭП бўлган 11 та бемордан 6 тасида (54,5\%) - 16-20 Гц атрофида, 5 та (45,5\%) беморда - 30-100 Гц, ва фақат 2 та бемор паст тонларни эшитмади. 
7-жадвал

Турли этиологияли ўткир ва тўсатдан сенсоневрал эшитиш пасайган беморларда эшитадиган товуш частоталарининг пастки чегараси

\begin{tabular}{|c|c|c|c|c|c|c|c|c|c|c|c|c|c|c|}
\hline \multirow{2}{*}{$\begin{array}{l}\text { № } \\
\text { T/p }\end{array}$} & \multirow{2}{*}{$\begin{array}{c}\text { ЎСНЭП ва } \\
\text { тСНЭП шакллари }\end{array}$} & \multirow{2}{*}{$\begin{array}{c}\text { Умумий } \\
\text { сони }\end{array}$} & \multicolumn{12}{|c|}{ Пастки чегара, Гц } \\
\hline & & & 16 & 18 & 20 & $21-25$ & $26-30$ & $31-40$ & $41-50$ & $51-60$ & $61-70$ & $71-80$ & $81-100$ & эшитмади \\
\hline \multirow[t]{3}{*}{1} & Юқумли & 29 & 10 & 4 & 4 & 3 & 2 & 1 & 1 & 1 & 0 & 1 & 1 & 1 \\
\hline & a) ЎСНЭП & 17 & 6 & 3 & 4 & 3 & 1 & & & & & & & \\
\hline & б) ТСНЭП & 12 & 4 & 1 & 0 & 0 & 1 & 1 & 1 & 1 & 0 & 1 & 1 & 1 \\
\hline \multirow[t]{3}{*}{2} & Қон томир & 18 & 9 & 1 & 1 & 1 & 1 & 1 & 0 & 1 & 1 & 0 & 1 & 1 \\
\hline & a) ЎСНЭП & 4 & 1 & 1 & 0 & 0 & 0 & 1 & & & & & & 1 \\
\hline & б) ТСНЭП & 14 & 8 & 0 & 1 & 1 & 1 & 0 & 0 & 1 & 1 & 0 & 1 & 0 \\
\hline 3 & $\begin{array}{c}\text { Аллергик } \\
\text { ЎСНЭП }\end{array}$ & 17 & 3 & - & - & - & - & 6 & 7 & 1 & - & - & - & 0 \\
\hline 4 & $\begin{array}{l}\text { Ототоксик } \\
\text { ЎСНЭП }\end{array}$ & 8 & 1 & 2 & 2 & - & - & - & - & 3 & - & - & - & - \\
\hline 5 & $\begin{array}{c}\text { Травматик } \\
\text { ЎСНЭП }\end{array}$ & 7 & 2 & 1 & - & - & - & - & 1 & 2 & - & - & - & 1 \\
\hline 6 & $\begin{array}{l}\text { Бўйин умуртқаси } \\
\text { остеохондрози } \\
\text { фонида (ТСНЭП) }\end{array}$ & 4 & - & - & - & - & - & 1 & - & 1 & - & - & 1 & 1 \\
\hline 7 & Жами & 82 & 25 & 8 & 7 & 4 & 2 & 9 & 9 & 9 & 1 & 1 & 3 & 4 \\
\hline
\end{tabular}


Қон томир шаклида (18 та бемор), тўсатдан эшитиш йўқолган 14 та бемордан 10 тасида эшитиш чегараси 16-30 Гц оралиғида, 4 кишида 30-100 Гц оралиғида бўлди. Қон томир этиологияли ЎСНЭП бўлган 4 та бемордан 2 тасида - 16-30 Гц, 1 тасида - 30-40 Гц ва 1 та бемор қабул қилинган частоталарнинг пастки чегарасини сезмади. Медикаментоз этиологияли ЎСНЭП бўлган 8 та бемордан 3 тасида эшитишнинг пастки чегараси 16-20 Гц, 3 тасида - 20-60 Гц оралиғида бўлди.

Травматик этиологияли ЎСНЭП бўлган 7 та бемордан 3 тасида эшитишнинг пастки чегараси 16-20 Гц, 3 тасида - 30-60 Гц оралиғида бўлди ва 1 та беморда пастки частота сезилмади, бу асосан эшитиш пастлиги бир томонлама юқори даражада бўлган беморларда кузатилди.

Бўйин умуртқаси остеохондрози туфайли эшитиш қобилиятини йўқотган 4 та беморнинг 3 тасида эшитишнинг пастки чегараси 30-100 Гц оралиғида бўлди, 1 та беморда пастки частота сезилмади. ТСНЭП билан касалланган 3 кишидан 2 тасида эшитиш бир томонлама ва фақат 1 та беморда икки томонлама пасайди. Аллергик табиатли ўткир сенсоневрал эшитиш пасайиши бўлган беморларда эшитишнинг пастки чегарасини ўрганиш натижаларини алохида таъкидлаш лозим.

Тадқиқотларимиз натижаларидан кўриниб турибдики, ушбу беморларда сенсоневрал эшитиш пасайишининг бошқа шакллари билан таққослаганда паст тонларни эшитиш чегараси ошган. Хусусан, аллергик этиологияли ЎСНЭП бўлган 17 нафар бемордан 6 тасида 30 - 40 Гц гача, 6 тасида - 16-20 Гц, 8 тасида - 40-60 Гц ва 0 тасида сезиладиган частоталар чегараси умуман аниқланмади.

Шундай қилиб, турли хил этиологияли ўткир ва тўсатдан эшитиш пасайиши бўлган беморларда сезиладиган частоталар спектрининг пастки чегарасини аниқлашда шуни таъкидлаш керакки, аксарият беморларда эшитишнинг пастки чегараси 16-20 Гц оралиғида бўлди, бу овозни қабул қилиш тизимининг шикастланганлигини билдиради, ўткир сенсоневрал эшитиш пасайишининг аллергик шаклида эшитишнинг пастки чегараси 20 Гц дан 60 Гц гачани ташкил этди, яъни эшитишнинг пастки чегараларида ўсиш кузатилди, бу эшитиш пасайишининг кондуктив таркибий қисми мавжудлигини тасдиқлайди. Ушбу усулни клиник аудиологияда қўллаш, агар суяк орқали эшитиш имконияти туфайли қулоқнинг ултратовушга сезгирлигини етарли даражада аниқлаб бўлмаганда, эшитиш анализаторининг ўткир шикастланишларида алохида ахамиятга эга. Бу холат, асосан, бир томонлама эшитиш пасайганда ёки чап ва ўнг қулоқда эшитиш қобилиятини йўқотиш даражасида сезиларли фарқ бўлганда юз беради. 
Шундай қилиб, бошқа аудиологик тестлар билан бир қаторда паст частотали товушлар билан эшитишни текшириш, бир томонлама эшитиш пасайишини текширишда, айниқса ултратовушни суяк орқали эшитишда катта диагностик ахамиятга эга.

Субъектив аудиологик тестлар билан бир қаторда биз объектив аудиометрия, тимпанограмма ўтказдик ва акустик рефлексни қайд этишни қўлладик.

Биз ЎСНЭП ва ТСНЭП бўлган 82 та бемордан 42 тасида объектив аудиометрия (импедансометрия) ўтказдик, бу 51,2\% ни ташкил қилади. Турли этиологияли ЎСНЭП ва ТСНЭП бўлган 42 та беморда тимпанометрия натижалари шуни кўрсатдики, 29 та (69,\%) беморда “А” типли, яъни нормал тимпанограмма тури қайд этилди, 8 та (19\%) беморда тубар дисфункция ёки ноғора бўшлиқда экссудат борлиги сабабли ноғора парда харакатчанлиги чекланганлигини кўрсатадиган “В” типи олинди ва фақатгина 5 та (11,9\%) беморда ноғора бўшлиқда салбий босим мавжудлигидан далолат берадиган “С” тури тимпанограмма қайд этилди. Текширилганларнинг 2 нафарида (25\%), аллергик этиологияли ЎСНЭП билан касалланган беморларда “В” типдаги тимпанограмма эгри чизиғи аниқланди. Худди шу беморлардаги рефлексометрия натижалари шуни кўрсатдики, 2 та беморда овознинг хам контралатерал ва хам ипсилатерал стимуляциясида хам акустик рефлекс кузатилмади, шу жумладан аллергик этиологияли ЎСНЭП да 2 та кишида ва 15 та беморда акустик рефлекс қайд этилди. 
Турли этиологияли ўткир ва тўсатдан сенсоневрал эшитиш пасайган беморларда импедансометрия натижалари

\begin{tabular}{|c|c|c|c|c|c|c|c|c|c|c|}
\hline \multirow{3}{*}{$\begin{array}{l}\text { № } \\
\text { T/p }\end{array}$} & \multirow{3}{*}{$\begin{array}{c}\text { ЎСНЭП ва ТСНЭП } \\
\text { шакллари }\end{array}$} & \multicolumn{3}{|c|}{ Тимпанограмма тури } & \multicolumn{4}{|c|}{ Акустик рефлекс } & \multirow{3}{*}{$\begin{array}{l}\text { Бемор- } \\
\text { ларнинг } \\
\text { умумий } \\
\text { сони }\end{array}$} & \multirow{3}{*}{$\begin{array}{l}\text { Текширил } \\
\text { ган } \\
\text { беморлар } \\
\text { сони }\end{array}$} \\
\hline & & \multirow{2}{*}{ «A» } & \multirow{2}{*}{ «B» } & \multirow{2}{*}{ «C» } & \multirow{2}{*}{ Йўқ } & \multirow{2}{*}{$\begin{array}{l}\text { Мав- } \\
\text { жуд }\end{array}$} & \multicolumn{2}{|c|}{ БОТФ мавжудлиги } & & \\
\hline & & & & & & & мусбат & ман-фий & & \\
\hline \multirow[t]{3}{*}{1} & Юқумли & 2 & 3 & 1 & 2 & 4 & 4 & 2 & 29 & 6 \\
\hline & a) ЎСНЭП & 1 & 2 & 1 & 1 & 3 & 3 & 1 & 17 & 4 \\
\hline & б) ТСНЭП & 1 & 1 & 0 & 1 & 1 & 1 & 1 & 12 & 2 \\
\hline \multirow[t]{3}{*}{2} & Қон томир & 6 & 1 & 0 & 3 & 4 & 4 & 3 & 18 & 7 \\
\hline & a) ЎСНЭП & 2 & 1 & 0 & 2 & 1 & 1 & 2 & 4 & 3 \\
\hline & б) ТСНЭП & 4 & 0 & 0 & 1 & 3 & 3 & 1 & 14 & 4 \\
\hline 3 & Аллергик ЎСНЭП & 14 & 2 & 1 & 2 & 15 & 14 & 3 & 17 & 17 \\
\hline 4 & Ототоксик ЎСНЭП & 2 & 1 & 2 & 2 & 3 & 3 & 2 & 8 & 5 \\
\hline 5 & Травматик ЎСНЭП & 2 & 1 & 1 & 2 & 2 & 2 & 2 & 7 & 4 \\
\hline 6 & $\begin{array}{c}\text { Бўйин умуртқаси } \\
\text { остеохондрози } \\
\text { фонида (ТСНЭП) }\end{array}$ & 3 & 0 & 0 & 0 & 3 & 3 & 0 & 4 & 3 \\
\hline 7 & Жами & $\begin{array}{c}29 \\
(69 \%)\end{array}$ & $\begin{array}{c}8 \\
(19 \%)\end{array}$ & $\begin{array}{c}5 \\
(11,9 \%)\end{array}$ & $\begin{array}{c}11 \\
(26,1 \%)\end{array}$ & $\begin{array}{c}31 \\
(73,8 \%)\end{array}$ & $\begin{array}{c}30 \\
(71,4 \%)\end{array}$ & $\begin{array}{c}12 \\
(28,5 \%)\end{array}$ & $\begin{array}{c}82 \\
(100 \%)\end{array}$ & $\begin{array}{c}42 \\
(51,2 \%)\end{array}$ \\
\hline
\end{tabular}


Шундай қилиб, аллергик этиологияли ЎСНЭП билан касалланган 2 та (25,6\%) беморда бир қатор ўзига хос хусусиятлар, яъни меъёрдан четга оғиш, “В” типдаги тимпанограмма эгри чизиғи ва акустик рефлекснинг йўқолиши, яъни сенсоневрал эшитиш пасайишининг бошқа шаклларига хос бўлмаган холатлар аниқланди. Бироқ ушбу одамларда ўтказилган аллергияга қарши даво ижобий натижалар берди: эшитиш яхшиланди, “А” типдаги тимпанограмма эгри чизиғи меъёрлашди ва акустик рефлекс қайд этилди.

Олинган далилларнинг изохини биз чиғоноқичи ўтказувчанлигининг бузилишида ва рецепторнинг функционал ўзгаришларида кўришимиз мумкин. Бунга аллергик омил сабаб бўлиши мумкин: А.Д.Адо ва хаммуаллифлар аллергияни асаб тизимини қўзғовчи сифатида ўрганган биринчи тадқиқотларидан буён, улар рецепторларга (қон томир, нафас рецепторлари ва бошқалар) фаол таъсир қилади деб хисобланади, кейинчалик бу йўналиш оториноларингологияда ривожланди. Хозирги кунда илм-фанда организм аллергиясида, ички кулоқнинг бошқа хосилалари хақида гапирилмасдан, эшитиш рецепторлари функциясида оғишлар бўлиши хақида жуда кўп маълумотлар мавжуд, улар хам тажрибада ва хам клиник кузатувларда тасдиқланган.

Бундай шароитларда биз аниқлаган қулоқ ичи акустик рефлексининг йўқолиши ушбу масала бўйича маълумотларни тасдиқлайди.

\section{IV. МУХОКАМА.}

Илмий иш аудиологик кўрсаткичларни, шунингдек аллергиянинг ЎСНЭП ривожланишидаги ўрнини ўрганишга бағишланган. Хозирга қадар эшитишнинг сенсоневрал ўткир ва тўсатдан йўқолиши битта тушунчага бирлаштирилган: ўткир кохлеар неврит, тўсатдан эшитишнинг пасайиши, тўсатдан карлик, эшитишнинг ўткир сенсоневрал пасайиши. Юзага келиш вақтига ва этиологик омилларига кўра уларни ўткир ва тўсатдан сенсоневрал эшитиш пасайишларига бўлинишига келсак, бундай тадқиқотлар деярли ўтказилмаган.

Айни пайтда, уларнинг хар бири илмий жихатдан хам, бевосита амалий жихатдан хам катта қизиқиш уйғотади. Шу билан бирга, бир қатор умумий саволларга аниқлик киритиш талаб этилади. Махаллий ва хорижий адабиётларда ушбу масалалар услубий ва фактлар нуқтаи назаридан етарли даражада ёритилмаган.

Кохлеар ва вестибуляр анализаторлар бир-бири билан чамбарчас боғлиқ ва ЎСНЭП да ички қулоқда чукур ўзгаришлар юз беради, шунинг учун уни ўз вақтида ва хар томонлама текшириш хозирги вақтда патологик холатларни эрта ташхислашда мухим рол 
ўйнайди. ЛОР бўлимида (ТТА кўп тармоқли клиникаси) биз турли хил этиологияли ЎСНЭП бўлган 24 та беморни клиник-аудиологик текширдик.

Умумқабул қилинган тадқиқот усулларидан ташқари, биз эшитиш функциясини бахолашда, субъектив қулоқ шовқинини частота ва интенсивлик бўйича тонал чегара аудиометриясидан фойдаландик, Вебернинг аудиометрик тести 125, 250, 500, 1000 Гц частоталарда аниқланди, юқори чегарадаги аудиометрия Фаулер бўйича товуш баландлиги мувозанатини аниқлаш (эшитишни бир томонлама йўқотишда) ва Люшер бўйича товуш кучини сезишнинг дифференциал чегарасини аниқлаш, товуш интенсивлигининг кичик ўсиш кўрсаткичларини аниқлаш - SI-SI (ёки “ИМПИ”), шунингдек, асосий частотаси 250 - 8000 Гц бўлган 1/3 октавали филтрланган шовқин таъсир эттирилганда эшитиш дискомфорти чегарасини аниқлаш амалга оширилди.

Эшитишнинг ўткир ва тўсатдан пасайишининг турли шаклларини дифференциал диагностика қилиш учун объектив аудиометрия (кулоқ ичи акустик рефлексини қайд қилиш кўринишида динамик импедансометрия ва тимпанометрия умумқабул қилинган усул бўйича) ўтказилди.

Аллергик характердаги ўткир сенсоневрал эшитиш пасайишида эшитиш функциясининг характеристикаси сенсоневрал эшитиш йўқолишининг бошқа шаклларига қараганда анча мураккаброқ кўринади, чунки ўткир эшитиш пасайишдаги аудиологик ва вестибулологик диагностика, шунингдек ушбу касалликнинг клиник хусусиятлари хали тавсифланмаган. Аниқки, ўткир сенсоневрал эшитиш пасайишининг этиологик жихатдан турли шакллари турли аудиологик хусусиятларга эга бўлади. Ўткир ва тўсатдан эшитиш пасайишининг хар бир шаклига хос хусусиятларни очиб бериш нафақат илмий, балки бевосита амалий ахамиятга хам эга.

Беморларни жинс бўйича тақсимланишини ўрганиш эшитишнинг ўткир ва тўсатдан пасайиши эркаклар орасида кенг тарқалганлигини аниқлади (14 та - 60\%.

Беморларнинг ёшга кўра тақсимланиши шуни кўрсатдики, касаллик тарқалиши асосан ёшларда, мехнатга лаёқатли 5-50 ёшгача бўлган одамларда максимал даражага етади - $22(75,8 \%)$.

Эшитиш қобилияти йўқолиш вақтига кўра биз беморларни икки гурухга ажратдик: биринчи гурухга эшитиш қобилияти тўсатдан, бир неча соатдан бир кунгача ёки 24 соат ичида юзага келган беморлар кирди. 2-гурухга бир кундан бир ойгача бўлган муддатда эшитиш қобилиятини йўқотганлар кирди. Улар ўткир сенсоневрал эшитиш пасайган (ЎСНЭП) беморлар деб таърифланди.

Анамнестик маълумотларни тахлил қилиш шуни кўрсатдики, беморларнинг аксарияти ЎСНЭП ва ТСНЭП ни юзага келтириши мумкин бўлган этиологик омилни 
кўрсатиб ўтдилар. ЎСНЭП куйидагилар кирди: 1) юқумли - 29 (35,4\%); 2) қон томирли 18 (21,9\%); 3) аллергик - 17 (20,7\%); 4) медикаменоз - 8 (9,7\%); 5) травматик - 7 (8,5\%); бўйин умуртқаси остеохондрози туфайли эшитишнинг пасайиши - 3 (3,8\%).

Текширувдан ўтган беморларда касалликнинг давомийлиги бир неча соатдан бир ойгача ўзгариб турди ва беморларнинг аксарияти эшитиш пасайгандан бошлаб икки хафта ичида касалхонага ётқизилган - 16 (40\%).

Аллергик табиатли ўткир сенсоневрал эшитиши пасайган беморларнинг кўпчилигида ЛОР аъзоларнинг объектив манзараси бурун шиллиқ қаватидаги патологик ўзгаришлар билан ажралиб турди, бу эса бошқа этиологияли ўткир сенсоневрал эшитиш пасайишига хос эмас.

Касалликнинг юқумли ва травматик этиологияли шакли билан оғриган ЎСНЭП ли беморларни хисобга олмаганда, отомикроскопик манзара меъёр даражасида бўлди: юқумли патологияда беморлар касалхонага ётқизилганда бурун шиллиқ қавати ва ноғора парданинг гиперемияси ва шишиши аниқланди, шунингдек аксарият беморларда - ноғора парданинг тортишиши ва ёруғлик рефлексининг етишмаслиги билан намоён бўладиган тубар (найча) функциясининг бузилиши аниқланди. Травматик этиологияли ЎСНЭПга келсак, минали-портлаш жарохатлари бўлган барча беморларда ноғора парданинг турли даражада зарар етганлиги қайд этилди.

Яхши аудиологик текширув аудиометрик эгри чизиқларни тавсифлашга, аудиограмманинг суяк-хаво интервалининг қиймати билан аудиограмма эгри чизиқларининг турли конфигурацияларида муайян алоқаларни ўрнатишга имкон берди. Олинган маълумотларнинг энг ахамиятлиси шундаки, товушларни суяк орқали ўтказишда эшитишнинг пасайиш даражаси хам, суяк-хаво интервали қиймати хам, қатор холларда, аллергия туфайли юзага келган ўткир сенсоневрал эшитиш пасайишини бошқа эшитиш пасайиши шакллари билан фарқлашда ишончли мезон бўлиб хизмат қилиши мумкин эмас.

Тонал бўсағали аудиометрия ўтказишда ЎСНЭП бўлган беморларнинг кўпчилигида бир томонлама эшитиш пасайиши аниқланди. Аллергик ва аллергик бўлмаган этиологияли ўткир сенсоневрал эшитиш пасайиши бўлган беморларда тонал аудиограмманинг бўсаға эгри чизиқлари сенсоневрал эшитиш пасайиши белгилари мавжудлигини кўрсатди, яъни эгри чизиқлар конфигурацияси пасайди, горизонтал пасайди ва горизонтал суяк - хаво интервали билан кузатилди. Бинобарин, аллергик табиатли ўткир сенсоневрал эшитиш пасайишида тонал чегарали аудиометриянинг ўзига хос хусусияти, бошқа шакллардан фарқ қилган холда, касалликнинг давомийлигига боғлиқ бўлмаган суяк-хаво интервали мавжудлигидир. Камертонал синовларга келсак, улар аниқ натижа бермади. Ринне тести кўпинча салбий бўлди, ва бу унинг суяк-хаво 
интервали қийматига ва товушни суяк орқали ўтказишда эшитиш даражасига боғлиқлиги ғоясига мос келади.

Аллергик табиатли ўткир сенсоневрал эшитиш пасайиши бўлган беморларда Вебернинг аудиометрик тести, бошқа турдаги сенсоневрал эшитиш пасайишларидан фарқли ўлароқ, эшитадиган кулокдаги тонларнинг латерализацияси ёмонроқлиги билан тавсифланади.

Товуш кучини сезишнинг дифференциал чегараси кўрсаткичи бўйича баландлик ошиши тезлашувининг феноменини аниқлаш кохлеар аппарат рецепторлари холати тўғрисида маълумот бериши мумкин, аммо усулнинг ўзи диагностика амалиётида етарлича асосларга кўра ишончли эмас. Бир қатор холатларда, чегара ва юқори чегара тестлари маълумотлари ўртасида келишмовчиликлар мавжуд бўлиб, уларни замонавий концепциялар асосида тушунтириш жуда қийин.

Умуман олганда, баландлик ошиши тезлашишининг манфий ва кучсиз мусбат феномени (БОТФ) аллергик, юқумли (шамоллаш) этиологияли ва баъзи бир травматик (мина-портловчи жарохатлар) этиологияли ўткир сенсоневрал эшитиш пасайишларида кузатилади, бунда аудиограмманинг чегара эгри чизиқлари суяк ўтказувчанлиги бўйича эшитиш пасайишининг даражасига боғлиқ бўлмайди. Аммо БОТФ йўқлиги кўпинча бошқа акуметрик ва аудиометрик маълумотларга кўра рецепторлари шикастланган деб тахмин қилиш мумкин бўлган беморларда кузатилади. БОТФ мусбат бўлган баъзи беморларда, аксинча, бошқа аудиометрик ва акуметрик маълумотлар чиғаноқнинг товушни сезувчи элементлари шикастини тасдиқламайди. Юқумли, қон томир этиологияли ва бўйин умуртқаси остеохондрози туфайли ТСНЭП билан оғриган беморларга келсак, улар товуш кучини сезишининг дифференциал чегараси ва SI-SI тести кўрсаткичлари бўйича баландликнинг ошиши мусбат ёки кескин мусбат феноменга эга, бу товуш қабул қилувчи аппаратда шикастланиш мавжудлигидан далолат беради. ЎСНЭП билан оғриган беморларда ушбу кўрсаткичлар кам намоён бўлди, кучсиз мусбат ёки кам сонли беморларда мусбат бўлди.

Эшитиш дискомфорти бўсағасини 1/3 октавали филтрланган шовқинни кўтара олиш кўрсаткичи бўйича ўрганиш шуни кўрсатдики, товушни сезадиган эшитиш пасайиши бўлган беморларда унинг бузилиши сезиларли фоизни ташкил қилади. Ушбу кўрсаткич, одатда, 1/3 октавали филтрланган шовқиннинг яхши кўтара олган ўткир сенсоневрал эшитиш пасайиши учун хос эмас.

Текширилган 82 нафар бемордан 48 нафарида (58,5\%) нутқни англаш қобилияти 100\% йўқолган, 34 та (41,6\%) беморда нутқни англаш қобилияти 100\% сақланган (34 та (100\%) ЎСНЭП билан касалланган беморда ва фақат 2 та (0\%) ТСНЭП билан касалланган 
беморда). Шуни таъкидлаш керакки, аллергик, юқумли ва травматик этиологияли ўткир сенсоневрал эшитиш пасайган беморларда нутқ интенсивлигининг 110 дБгача кўтарилиши, бошқа шакллардан фарқли ўлароқ, нутқни англашнинг ёмонлашишига олиб келмайди. Шу билан бирга, ўткир сенсоневрал эшитиш пасайишининг аллергик бўлмаган шаклида, нутқни англаш эгри чизиқлари текис бўлиб, 100\% англашга эришилмайди.

Бинобарин, нутқ аудиометрияси натижалари шуни кўрсатдики, ТСНЭП билан оғриган беморларнинг кўпчилигида нутқни англаш бузилган, бу ички қулоқнинг овоз қабул қилувчи аппарати шикастланганлигини кўрсатади.

Ўткир ва тўсатдан сенсоневрал эшитиш пасайган 24 нафар беморда эшитиш бузилишларининг мохиятини аниқлаш учун биз ултратовушга товуш сезгирлигини Б.М.Сагалович бўйича аниқладик. Тўсатдан сенсоневрал эшитиш пасайган беморларда ултратовушга эшитиш сезувчанлигини аниқлаш натижалари алохида эътибор талаб қилади. Ултратовушни сезиш чегараси 10 волтдан 30 волтгача кўтарилган ўткир сенсоневрал эшитиш пасайишидан фарқли ўлароқ, юқумли, қон томир, аллергик, травматик ва медикаментоз этиологияли ЎСНЭПда ултратовушни нормада сезиш ёки унинг 3 дан 10 волтгача кўтарилиши характерлидир.

Биз эшитиши ўткир ва тўсатдан пасайган барча беморларда ултратовушни латерализация қилиш феноменини тонал аудиограммалар эгри чизиқларининг турли хил конфигурацияларида эшитиладиган спектр тонларининг латерализацияси билан таққослаб ўргандик.

ЎСНЭП билан оғриган беморларда ултратовушнинг латерализациясини аниқлашда беморларнинг аксариятида эшитадиган қулоқда ёмонроқ латерализация бўлишини кўрсатди. Бу юқумли, қон томир этиологияси ва бўйин умуртқалари остеохондрози туфайли юзага келган тўсатдан сенсоневрал эшитиш қобилияти йўқолган беморларда кўпроқ учради.

Ўткир ва тўсатдан сенсоневрал эшитиш пасайиш учун аудиологик мезонларни белгилашда кичик ахамият касб этмаган нарса, сезилган частоталарнинг пастки чегарасини ўрганишдир. Ушбу тадқиқот ултратовушни яхши эшитадиган қулоқ орқали такрор эшитиш учун шароитлар пайдо бўлганда, эшитиш бир томонлама ёки икки томонлама (чап ва ўнг қулоқдаги эшитиш қобилиятини йўқотиш даражасида сезиларли фарқ билан) пасайган беморларда алохида ахамиятга эга. Тадқиқотлар шуни кўрсатдики, ЎСНЭП билан касалланган беморларнинг кўпчилигида ушбу чегара ўнг томонга 50 Гц гача силжиган, бу эса кондуктив эшитиш пасайиши мавжудлигини тасдиқлади.

Субъектив аудиологик тестлар билан бир қаторда биз объектив аудиометрия, тимпанограмма ўтказдик ва акустик рефлексларни текширдик. 
Биз ЎСНЭП бўлган 82 та бемордан 42 тасида объектив аудиометрия (импедансометрия) ўтказдик, бу 51,2\% ни ташкил қилади. Турли этиологияли ЎСНЭП бўлган 42 та беморда тимпанометрия натижалари шуни кўрсатдики, 29 та (69,\%) беморда “А” типли, яъни нормал тимпанограмма тури қайд этилди, 8 та (19\%) беморда тубар дисфункция ёки ноғора бўшликда экссудат борлиги сабабли ноғора парда харакатчанлиги чекланганлигини кўрсатадиган “В” типи олинди ва фақатгина 5 та $(11,9 \%)$ беморда ноғора бўшликда салбий босим мавжудлигидан далолат берадиган “С” турдаги тимпанограмма қайд этилди. Текширилганларнинг 2 нафарида (25\%), аллергик этиологияли ЎСНЭП билан касалланган беморларда “В” типдаги тимпанограмма эгри чизиғи олинди ва турли этиологияли ЎСНЭП ва ТСНЭП бўлган ушбу беморларда рефлексометрия натижалари шуни кўрсатдики, 31 та беморда товушнинг хам контралатерал ва хам ипсилатерал стимуляциясида акустик рефлекс кузатилди, 11 нафар (26,1\%) беморда акустик рефлекс кузатилмади, шу жумладан аллергик этиологияли ЎСНЭП да 2 та беморда акустик рефлекс қайд этилди.

Шундай қилиб, аллергик этиологияли ЎСНЭП билан касалланган 2 та (25,6\%) беморда бир қатор ўзига хос хусусиятлар, яъни меъёрлардан четга оғиш, “В” типдаги тимпанограмма эгри чизиғи ва акустик рефлекснинг йўқолиши, яъни сенсоневрал эшитиш пасайишининг бошқа шаклларига хос бўлмаган холатлар аниқланди. Бироқ ушбу одамларда ўтказилган аллергияга қарши даво ижобий натижалар берди: эшитиш яхшиланди, “А” типдаги тимпанограмма эгри чизиғи мељёрлашди ва акустик рефлекс қайд этилди.

Шундай қилиб, хулоса қилиб айтганда, ўткир ва тўсатдан сенсоневрал эшитиш пасайиши кохлеар анализатор патологиясининг мустақил нозологик шакллари хисобланади ва этиопатогенезига кўра клиник кечишида ўзига хос хусусиятларга эга, бу эса замонавий клиник аудиологиянинг келгусида ўрганиш учун катта истиқболларга эга бўлган мухим муаммоси сифатида таърифланади.

\section{V. ХУЛОСА.}

Клиник кечиши ва пайдо бўлиш тезлигига кўра, тўсатдан сенсоневрал эшитиш пасайиши (24 соатгача ривожланиб боради) ва ўткир сенсоневрал эшитиш пасайиши (бир кундан 30 кунгача ривожланади) фарқланади. Ўткир сенсоневрал эшитиш пасайиши кўпинча вертебробазиляр хавзада гемодинамик бузилишлар натижасида томирлар патологияси (артериал спазм, вазодилатация, веноз димланиш, қон томир деворидаги атеросклеротик ўзгаришлар, Б шаклидаги деформация ёки умуртқа артерияларининг қийшайиши) фонида, шунингдек, вирусли инфекция натижасида ва оғир аллергик 
анамнезга эга бўлган шахсларда ривожланади. Ўткир сенсоневрал эшитиш пасайиши 92\% холларда икки томонлама бўлади, эшитиш қобилиятининг аста-секин пасайиши билан ажралиб туради ва 78,7\% - баланд овознинг тезлашган мусбат феномени мавжудлиги билан тавсифланади. Аллергик анамнезга эга одамларда ўткир сенсоневрал эшитиш пасайиши ривожланиши мумкин. У аутофония, турли интенсивликдаги қулоқнинг субъектив шовқини, бош ва қулоқдаги оғриқлар ва вестибуляр функцияларнинг бузилиши (беморларнинг 52\%да) билан бирга кечади. Аллергик этиологияли ўткир ва тўсатдан эшитиш қобилиятини йўқотиш бир қатор аудиологик белгилар (суяк-хаво интервали бўлмаган аудиологик эгри чизиқларнинг тушиб борувчи конфигурацияси, ултратовушга нисбатан эшитиш сезгирлигининг бироз ошиши; нутқни $100 \%$ англаш) билан тавсифланади, бу кохлеар рецепторда функционал силжишлар билан биргаликда ички кулоқда товуш ўтказувчанлик бузилишларининг комбинациясини билдиради. Аллергия фонида келиб чиқадиган ўткир эшитиш пасайишида, 11,2\% беморларда ноғора бўшлиқда экссудат борлиги, акустик рефлекснинг йўқлиги ва хаво-суяк бўшлиғининг пайдо бўлиши сабабли “В” типдаги тимпанограмма қайд этилди.

\section{VІ. ФОЙДАЛАНИЛГАН АДАБИЁТЛАР РЎЙХАТИ}

1. Пальчун В.Т., Магомедов М.М., Лучихин Л.А. Оториноларингология: учебник. М.: ГЭОТАРМедиа, 2008. /Palchun VT, Magomedov MM, Luchikhin LA. Otolaryngology: a guidebook. M.: GEOTAR-Media, 2008.

2. Кунельская Н.Л., Полякова Т.С. Патогенетические аспекты нейросенсорной тугоухости и их коррекция. Мат. XVIII съезда оториноларинголов России. СПб., 2006: 33-34. 1

3. Пальчун В.Т. Оториноларингология: Руководство для врачей / В.Т. Пальчун, А.И. Крюков. - М.: Медицина, 2001. - 616 с.

4. Таварткиладзе Г.А., Загорянская М.Е., Румянцева М.Г. и др. Методики эпидемиологического исследования нарушений слуха. Методические рекомендации. M., 2006. 27 c. /

5. Шидловская Т.В. Шидловская Т.Ф. Комплексное лечение сенсоневральной тугоухости. Российская оториноларингология (приложение), 2007: 700-705

6. Глухота и потеря слуха. Информационный бюллетень ВОЗ. №300. Март 2015 г. http://www.who. int/mediacentre/factsheets/fs300/en/.

7. Косяков С.Я., Атанесян А.Г. Интратимпанальное введение стероидов в лечении острой сенсоневральной тугоухости // Российская оториноларингология. - 2009. - № 6. - C. $51-59$. 
8. Т.А. Сичкарева, В.В. Вишняков, Д.Е. Кутепов. Перспективные методы лечения сенсоневральной тугоухости / Т.А. Сичкарева, В.В. Вишняков, Д.Е. Кутепов // Вестник оториноларингологии. - 2007. - № 5. - Приложение. - С. 121-122.

9. Беличева Э.Г. Острая и внезапная сенсоневральная тугоухость: этиология, клиника, диагностика, эффективность ранней этиопатогенетической терапии: автореф. дис. ... д-ра мед. наук / Э.Г. Беличева. - Санкт-Петербург, 2008. - 41 с.

10. Бакулина Л.С., Машкова Т.А. Сенсоневральная тугоухость: этиология, терапия и реабилитация. Современные проблемы физиологии и патологии слуха: матер. 2-го Национального конгресса аудиологов и 6-го Международного симпозиума. Суздаль, 2007: 44-45.

11. Загорянская М.Е., Румянцева М.Г. Значение эпидемиологических методов исследования в профилактике нарушения слуха у детей. Рос. оторинолар., 2003, 6(3): $79-83$.

12. Иванец И.В. Острая и внезапная нейросенсорная тугоухость (клиникоэкспериментальные исследования): Автореф. дис... д-ра мед. М., 2001. 42 с.

13. Глухота и потеря слуха. Информационный бюллетень ВОЗ. №300. Март 2015 г. http://www.who. int/mediacentre/factsheets/fs300/en/.

14. Левина М.А. Этиопатогенетические аспекты сенсоневральной тугоухости. Вестник оториноларингологии, 2015, 80(6): 77-81. /Levina MA. Etiopathogenetic aspects of sensorineural hearing loss. Vestnik Otorinolaringologii, 2015, 80 (6): 77-81.

15. Левина Е.А. Сенсоневральная тугоухость - общие принципы медикаментозного подхода. Consilium Medicum, 2013, 11: 64-67. /Levina EA. Sensory neural hearing loss: the general principles of pharmaceutical approach. Consilium Medicum, 2013, 11: 64-67

16. Martines F., Dispenza F., Gagliardo C., Martines E., Bentivegna D. Sudden sensorineural hearing loss as prodromal symptom of anterior inferior cerebellar artery infarction // Arch neurol. - 2001. - Vol. 53. № 45. - P. 1287-1289. doi:10. 1001/ archneur. 58.8.1287. 